\title{
The Important Role Teaching Pragmatics Plays in Translation Classes:with Reference to Translation Teachers' Questionnaire
}

\begin{abstract}
:
There can be no doubt that translation students need to know a good deal about grammar, rhetoric, terminology, and semantics in order to be competent translators. However, students also need to be knowledgeable at the pragmatic level which is totally neglected by most translation teachers in the department of translation in Constantine University 1, Algeria. Thus, this paper attempts to shed light on translation teachers evaluation of the pragmatic knowledge and competence of translation students. The main aim of this paper is to show how important pragmatics is to translation students. In an attempt to realize the aim of this paper a questionnaire was given to twelve translation teachers. The questionnaire findings show that almost all translation students suffer from incompetence at the pragmatic level.

Key words: Teaching translation. Teaching pragmatics.Arabic.English.
\end{abstract}

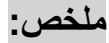

$$
\begin{aligned}
& \text { ليس هناك شك في أن طلاب الترجمة في حاجة إلى معرفة } \\
& \text { الكثير عن قو اعد اللغة والبلاغة والمصطلحات و الدلالات من } \\
& \text { أجل أن يكونوا مترجمين أكفاء إضافة إلى ذلك فهم ملزمون } \\
& \text { بأن يكونوا على دراية بقواعد علم البراغماتية الذي أهمل } \\
& \text { بدوره تماما من قبل معظم أساتذة الترجمة في عدة جامعات } \\
& \text { في العالم و في قسم الترجمة بجامعة قسنطينة خاصة.لذلك } \\
& \text { فالهدف الرئيسي لهذا المقال هو إظهار مدى أهمية علم سياق } \\
& \text { كلام النص أو البراغماتية لطلاب الترجمة. في محاولة } \\
& \text { لتحقيق هذا الهدف طلب من اثني عشرة أستاذ ترجمة الإجابة } \\
& \text { على الاستبيان الذي أظهرت نتائجه أن كل طلاب الترجمة } \\
& \text { تقريبا يعانون من عدم الكفاءة على المستوى البراغماتي. }
\end{aligned}
$$

\section{Manel TRIKI}

Faculty of Letters and Languages Department of Foreign Languages University of Mentouri

Conctontino

\section{Introduction : \\ Translation is not an easy task due to} differences between languages and cultures. Thus, translation teachers and translation students should be competent in different areas of language such as, syntax, semantics, pragmatics, culture, and so on. Teaching translation is considered one of the central issues in communication fields and the translator plays a great role as a transmitter of culture from one language and society to another. More important, translation operates at different language levels and therefore different aspects should be taken into account when learning and teaching translation; i. e., translation teachers should not focus on improving only the grammar and syntax of translation students; they should rather 
work on making translation students aware of the importance of pragmatic factors in translation because translation errors are not found only at the grammatical level. Thus, it is necessary to understand language which is appropriate to the situation in which it is functioning and failure to do so may lead translation students to mistranslate key points. The main concern of this paper, therefore, is to show and explain how the area of pragmatics is important to be integrated in teaching translation to students in the department of translation in Constantine University 1, Algeria.

\section{Translation Equivalence}

Almost all scholars and translators agree that equivalence is the most important part of translation. Accordingly, translation has been divided by scholars into different types such as formal vs dynamic equivalence (Nida, 1964), semantic vs communicative translation (Newmark, 1991), semantic vs functional equivalence (Bell, 1991), covert vs overt translation (House, 2001), non- pragmatic vs pragmatic equivalence (Willss, 1982). This dichotomy deals with translation from the principle of equivalence between the source and the target texts. However, equivalence can differ from one translation to another, i.e., there are different degrees of equivalence. Baker (1992) proposes that translation equivalence is much more related either to the form/ the meaning of the text, and to the cultural norms of both languages; or to the effects the source and the target texts may have on readers. Nida (1964) distinguished between two types of equivalence, formal and dynamic equivalence. Sometimes formal equivalence is referred to as literal equivalence. Hatim and Munday (2004), argue that formal equivalence or formal correspondence is the relationship between the source and the target texts in which the replacement of words is purely formal. Yet, this type of equivalence does not always serve the message of the source text when translating it into the target language, i.e., translating the original linguistic unit; the grammatical structure, and punctuation and neglecting the meaning and the extra linguistic factors of the original text may lead to violation of some aspects while translating. Hence, formal equivalence cannot always be regarded as a good translation. Nida's (1964: 166) translation of the Bible where the phrase "lamb of God" is rendered into "seal of God" for the Eskimo because lamb does not symbolize innocence in their culture is a case in point. The second type of equivalence for Nida and Taber (1982) is dynamic equivalence. They define it as the translation principle in which a translator translates the source text meaning producing the same effect and impact on the target text audience as it is the effect upon the source text audience. In other words, applying dynamic equivalence, the translator tries to read and understand the thoughts and ideas in the source text then translate them into the target language regardless of the form. Thus, what matters here for a translator is the fact that s/he is not dealing only with different languages; rather s/he is dealing with different cultures too. Furthermore, Koller names it differently as pragmatic equivalence or for some others communicative or 
functional equivalence. It is oriented towards the receptor of the text, as s/he should receive the same effect that the original text produces on its readers (Koller, 1977).

From another perspective, Catford (1965) supposes that nonequivalence is due to two factors which are linguistic factors and cultural/ pragmatic factors. Consequently, two types of equivalence can emerge here, linguistic equivalence and cultural or pragmatic equivalence. The latter is concerned with the extra linguistic factors, while the former deals more with grammar, structure and vocabulary of language as well as the semantic field of the language. That is to say, unlike linguistic equivalence, the first concern of pragmatic equivalence is not how to connect sentences and paragraphs together with identifying textual features, rather it is how sentences are used in a communicative way and how they can be interpreted in context.

\section{The Importance of Pragmatic Knowledge in Translation}

To start with, a definition of pragmatics and the relationship between pragmatics and translation are needed to be discussed. Yule (1996) defines pragmatics as the study of meaning as communicated by a speaker (or writer) and interpreted by a listener (or reader). It has, consequently more to do with the analysis of what people mean by their utterance than what the words or phrases in those utterances might mean by themselves. Furthermore, pragmatics is the study of language use and language users. It is the relationship that exists between the sentence or the utterance and the user of this utterance. It is concerned with bridging or lining between sentences meaning and speakers' intention. More importantly, the real meaning of an utterance can be discovered by the analysis of contextual meaning through pragmatics. Here, one should bear in mind the fact that the function of a language is not only to report events in the world. Language also is used to convey messages that are full of cultural aspects which are very useful in the communication process. That is to say, texts do not have meanings; rather, in producing texts people intend meaning. So, the translator as a producer of texts, attempts to understand first the author's intended meaning in the source text, then he should create a target text which is equivalent to the source text and which has the same intended meaning and impact on the audience of the source text (Ballim and Wilks, 1991). In other words, when a translator comes to translate a given utterance s/he should take into account not only the grammar and meaning of the utterances, s/he should consider the actions the speaker implies in her/his utterances when uttering them.

In order to better understand an utterance, the participants should be pragmatically competent. That is to say, in any conversation there is always the information about the world interior to the conversation and the information 
about the exterior to the conversation. The translator before starting any translating task should be aware of the pragmatic dimensions of the conversation in hand; hence a pragmatic knowledge is needed for any translator. For instance, Austin (1961) gives the example of producing the utterance "I do" in a marriage ceremony. He says that uttering 'I do' is doing an action since it is clear that the utterance ' $\mathrm{I}$ do' in this context is neither to describe nor to state something, rather it is to perform and do an action. Moreover, the utterance can be considered neither true nor false. In an attempt to translate Austin's example into Arabic literally, instead of saying "I do", Arabic participants may say "أنافعل", which is here not equivalent to the English reply. A better translation can be "أنامو "، ", which means I agree. This means, to reach an authentic translation the translator should first produce a correct grammatical sentence. Second, s/he should maintain the same intended or implied meaning of the source utterance in the target text. Third, the translator has to produce in his/her translation the same effects the source utterance has on its audience. To achieve all this, the translator should pass through the locutionary, illocutionary, and perlocutionary phases when translating a certain text, in addition to coming across other different pragmatic aspects such as, cooperative principle, implicatures, presuppositions and entailments, etc. However, Bariki (in press) writes that pragmatic aspects are not universal, especially in languages that have totally different cultures; in this case pragmatic problems can occur when translating. In other words, a translator should use his/her cross-cultural pragmatic knowledge in order to appropriately convey his/her message into the target language without causing any offence. Pragmatic aspects, as many linguists have claimed, differ crossculturally, so that the translator first should work to achieve a cross-cultural pragmatic understanding. This can only be attained if the translator is familiar with pragmatic aspects that the source and the target texts include (Bariki, in press.). More importantly, it is worth remembering here that an informed translator has to recontextualize the situation in which the original text is embedded as an attempt to convey meaning and aid target readers to better understand the original meaning. Accordingly, the translator may achieve a corresponding effect on his new readership (Ehrman, 1993). This means that the translator should be familiar with the surrounding extra-linguistic dimensions of the original text which form a communicative event.

One of the main purposes of translation is communication. Nevertheless, many translation students are surprised when they realize that in spite of succeeding to produce grammatically correct translations, they still have difficulties at the pragmatic level when translating English/ Arabic/ English texts. This can be accounted for by the lack of communicative and pragmatic competence (Hymes, 1964). That is to say, translation students are in need of knowledge and experience to correctly interpret the socio-cultural 
norms of the source language. Many studies (Blum-Kulka, 1982; Cohen and Olshtain, 1981, among others) have shown that these norms vary from one culture to another. Thus, translation students require more than just linguistic knowledge to communicate effectively then to interpret and translate appropriately. In this sense, Thomas (1983) distinguishes between two types of competence that translation students need: grammatical competence and pragmatic competence. The former refers to the knowledge of phonology, syntax, semantics, etc. and the latter refers to the ability to use a language effectively in order to fulfill a certain goal and to understand language in context (Thomas, 1983). Therefore, a translation student needs to be competent at the level of grammar and pragmatics. However, translation teachers in the department of translation in Constantine University 1, Algeria, most of the times focus only on teaching students how to gain grammatical competence, and overlook the teaching of pragmatics to translation students. This method in teaching can be attributed to the lack of some valid methods for testing interlanguage pragmatic knowledge. The resulting lack of pragmatic competence among translation students can lead to pragmatic failure. Hence, it can be said that teaching pragmatics plays an important role to translation students.

\section{Teaching Translation}

The teaching of translation may be described as the transfer of translational competence from teacher to students; this is obviously more easily said than done (Mauriello, G. 1991). According to Ingo, R. (1991), in teaching translation teachers should pay attention to four fundamental aspects which are grammatical structure, linguistic variety (especially style), semantics, and pragmatics. He adds that those aspects are important in teaching translation, either for teachers or learners since they provide a good starting-point for assessing the quality of a translated text.

In teaching translation, it is necessary to take into account the impact of cultural and linguistic situations in which a certain text is produced. Texts are usually produced in a certain point of time, for a certain purpose, in a certain cultural and educational environment, etc. These factors may differ from one text to another which makes different kinds of adjustments necessary. Thus "the translated text must function pragmatically in its new cultural context" (Inga, 1991: 55). Teaching pragmatics, therefore, should be considered as important as teaching grammar to translation students.

Several translation teaching specialists have discussed the importance of choosing the most appropriate approach in teaching translation. Some of them, such as Ladmiral (1977), focus on the teacher as the central part in teaching translation. Others like, Holz-Manttari (1984) and Newmark (1981), 
claim that students are the central element in teaching translation, while Van Den Broeck (1980) and Toury (1980) suggest that in teaching translation the focus should be on the type of the text in hand. These three views or approaches called are "teacher-centered approach, students-centered approach, and text type-oriented approach" respectively.

\section{a- Teacher-Centered Approach}

This is a traditional approach in teaching translation. Ladmiral describes this approach as "the more or less faulty performances of students are the trials and errors that mark the itinerary that must take them to the level of the instructor, which is considered the ideal" (Ladmiral, 1977: 508). He adds that the teacher-centered approach "is the complete replacement of the linguistic norms with pedagogical ones that allows translation teaching to ignore a 'feel' for the foreign language" (Kiraly, 1995: 21). Furthermore, HolzManttari sees that the teacher centered approach in teaching translation concentrates more on students' grammatical errors which leads them to neglect the translation performance (Kiraly, 1995).

Ladmiral proposes that in this approach teachers have to break the method of teachers' performance in classroom practice and move away from a focus on the eradication of errors toward the positive development of students' knowledge and skills (Kiraly, 1995).

\section{b-Student-Centered Approach}

inKiraly (1995), Holz-Manttari emphasizes the value of this approach. She maintains that the student-centered approach should be considered as a primary objective of translator training program. She adds that it is not only the teacher's responsibility to make students see alternatives; rather it should be a mutual task between translation teachers and students (Kiraly, 1995). In other words, "the task of the instructor is to show various paths to learners and to make students independent from himself. The graduate will then later be able to adapt to and act responsibly in any professional situation" (Kiraly, 1995: 21).

According to House (2001), following this approach in teaching translation should emphasise students' independence from the teacher, i. e. the students' own participation in the selection and production of original texts for translation, in addition to the integration of spoken and written language in the translation instruction process.

\section{c- Text Type-Oriented Approach}

Van Den Broeck (1980) and Toury (1980) describe text type-oriented approach of teaching translation as a method in which translation norms and pragmatic text considerations play an important role. In this approach, teachers provide students with tools not for producing the ideal translation but to make 
students able to deal with text-specific and situation-specific variables, and to produce a correct translation under the given circumstances (Kiraly, 1995). Moreover, Delisle (1984) suggests that text type-oriented approach in teaching translation is first to understand the source text, second to extract the extra linguistic sense from the source text, and third to reformulate the extracted sense in the target language. Interestingly, in this approach translation teachers push students to the way how to identify and extract the extratextual factors by observing the situation in which the text is used (Delisle, 1984).

\section{Analysis and Interpretation of the Teachers' Questionnaire}

Nine translation teachers out of twelve completed the questionnaire, i.e., the return rate of the questionnaire was $75 \%$. This latter can be described as relatively high. All teachers were from the department of translation at Constantine University 1, Algeria. Six teachers who completed the questionnaire hold an MA (Magistere) degree, while three teachers hold a $\mathrm{PhD}$ (Doctorate) degree. Moreover, all the teachers who completed this questionnaire are full time lecturers; $44.44 \%$ of them have more than eighteen years of experience in teaching translation, which means that they are quite experienced in teaching at the university level. All of them teach at least two modules.

\section{Question Item One}

"How would you rate the learners' pragmatic knowledge? Good ... Average ... Bad ...?"

This question investigates how translation teachers evaluate students' pragmatic knowledge. Eight teachers out of nine (88.88\%) considered students' pragmatic knowledge as bad. Only one teacher saw that students' pragmatic knowledge is average; and no teacher said that students' pragmatic knowledge is good. The main reasons behind the translation' students bad level in pragmatics can be that pragmatics is not taught in the department of translation in Constantine University 1; as it can be due to translation teachers failure in transmitting their pragmatic knowledge to their students.

\section{Question Item Two}

What is the most common strategy fourth year translation students resort to when they come across culturally loaded expressions in translation (such as idioms)?

a. Translate them literally.

b. Apply a dynamic / pragmatic equivalence in translation.

c. Look for any equivalent idiom in the target language. 


\section{d. Others.}

The aim behind this question is to see whether or not students give any importance to pragmatic aspects in translation. Teachers were asked about strategies translation students may use when translating culturally loaded expressions such as idioms. It was no surprise to read in the results that teachers answered that the students in this case translate expressions literally. That is to say, $88.88 \%$ of teachers (eight teachers out of nine) believed that students use literal translation in translating culturally loaded expressions, while only one teacher answered that students in this case use a formal equivalence to translate the expression. This means that students either do not give any importance to pragmatic aspects and cultural factors in translation or that their pragmatic and cultural knowledge is not good enough to find equivalents to such culturally loaded expressions. This can be mainly due to the fact that pragmatics is not taught to translation students.

\section{Question Item Three}

What are the possible teaching techniques you may resort to and which may help the learners overcome translation pragmatic problems?

The aim of this question is twofold. On the one hand, this question aims at investigating translation teachers' techniques in helping learners to overcome translation pragmatic problems. On the other hand, the question aims at showing the importance of teaching pragmatics to translation students, and this can be seen in teachers' answers. In question item three teachers were requested to give possible teaching methodologies and techniques which they may apply to help learners overcome translation pragmatic problems. However in answering this question teachers did not provide a good amount of detail about the methodologies they usually use to help translation students to overcome pragmatic problems.

Techniques that had been suggested by teachers are as follows:

a. Students should be taught pragmatics as a separate module at the beginning of their studies through which they should be adequately informed in pragmatics.

b. Give students pragmatic lessons during their translation classes.

c. Motivate students to read about pragmatics in translation and about translation equivalence as much as possible.

d. Push students to evaluate their own translations, and then correct themselves.

e. Advise translation students to read and listen in both languages (source and target languages).

Techniques ' $a$ ' and ' $b$ ' were the ones given by many teachers, i.e., $55.55 \%$ of teachers suggested those two techniques in order to help students to 
overcome translation pragmatic problems. The teachers' emphasis here was much more on the integrating of teaching pragmatics to translation students at the Department of Translation in Constantine University 1. One more thing which is worth mentioning is that one teacher out of nine teachers wrote that there is no teaching technique which may help students in this case as long as most of students do not give any importance to the pragmatic and cultural aspects of languages in translation.

It can be said in general that teachers gave an approach that can be characterized as student-centered approach. That is to say, it is a studentdirected methodology in a way where teachers are supposed just to transmit pragmatic information to their students. To overcome any problems in language use the learner should at first develop his/her competence in that language. Hence, the development of pragmatic competence according to Ellis (1994), depends on providing learners with sufficient and appropriate input. This latter in translation classes may come mainly through lessons in pragmatics provided by teachers, and students' practice at the pragmatic level, and then to evaluate students' end product from a pragmatic perspective by students themselves and also by teachers. Yet, this is not available as a methodology in the Department of Translation in Constantine University 1 since translation teachers follow mainly a traditional way of teaching in the classroom, that is, teacher-centered approach.

\section{Question Item Four}

Are fourth year students aware of the importance of pragmatic knowledge in translation?

In question item four, teachers were asked whether or not fourth year translation students are aware of the importance ofpragmatic knowledge in translation. From the answers obtained, $88.88 \%$ of the respondents answered that not all students are aware of the importance and the role pragmatic knowledge plays in translation. Eight teachers out of nine saw that translation students are not aware of the importance of pragmatic knowledge in translation. Interestingly, this can be due to the fact that pragmaticshas never been taught as a separate module at the Department of Translation in Constantine University 1. Moreover, almost all translation teachers are well knowledgeable in pragmatics, furthermore they are aware of pragmatic equivalence importance in translation; yet they could not appropriately transmit this knowledge to their students in class.

\section{Question Item Five}

What are your beliefs (as a teacher) about using translation in teaching English? 
In this question teachers were asked about their beliefs concerning using translation in teaching English. In answering this question, teachers' answers were divided into two categories. First, three teachers out of nine (or $33.33 \%$ ) believed that the use of translation to learn English is a useless method and old-fashioned strategy in learning languages. This means, on a daily basis and for years a language can be learnt by reading and listening, not by translating words and expressions from one language into another. Second, six teachers out of nine ( $66.66 \%$ of them) answered that translation may help students to learn English at an early stage such as leaning English vocabulary and grammar but not to learn the whole system of the language. That is to say, translation can help students to learn basic matters in English, yet the fundamental aim of learning translation is to translate.

\section{Further Comments}

According to teachers' answers to the questionnaire almost all teachers who completed the questionnaire were aware of the importance of pragmatic knowledge in translation as well as the importance of teaching pragmatics in the department of translation as a separate module. However, they did not make the necessary efforts in order to transmit their knowledge, experience and awareness concerning pragmatics in translation. This can be due to different reasons such as teachers being obliged to follow a certain program in teaching translation in the Department of Translation in Constantine University 1.

More importantly, to make a noticeable improvement in the students' level in pragmatics this latter should be taught in the department of translation in CU1 since translation teachers seldom, if ever, taught pragmatic knowledge in classes. That is to say, one way of remedying this lack of direct exposure to the target culture and society may be through teaching pragmatics to translation students. The questionnaire results show that translation teachers in the Department of Translation in CU1 believe that teaching pragmatics to translation students would help improve students' skills and competence in translation.

Another point which is worth mentioning is all translation teachers in Constantine University 1 are not native speakers of English, which means that teachers themselves are exposed to make pragmatic and cultural errors when translating English / Arabic texts. Thus, they cannot draw on native speakers' intuitions and cannot serve as direct models for the students (Bardovi-Halig and Hatford, 1996). In this case, two methodologies or two types of activities can be proposed for translation teachers: Activities aiming at raising students' pragmatic awareness, and activities offering opportunities for communicative practice when 
translating English / Arabic texts (Kasper, 1997). Rose (1994) adds that if the learners pragmatic consciousness is raised, s/he will easily notice pragmatic features of the input and this way can lead to the acquisition of pragmatic knowledge.

The findings are not generalizable because of the limited sample. However, they could be revealing of issues in similar contexts. A wider survey would yield more trustworthy results.

\section{Conclusion}

To conclude it can be said that fourth year translation students at the Department of Translation in Constantine University 1 have a noticeable weakness at the pragmatic level. As a possible suggested solution in order to enhance students' pragmatic skills in translation is that there is a need for teachers at the Department of Translation in Constantine University 1 to develop their teaching techniques. In other words, instead of using oldfashioned methodologies in translation classes and depending only on a teacher-centered approach, teachers should use more learner initiated and awareness focused activities, as well as recommending a reading series, and texts which are mostly provided with pragmatic and cultural aspects in order to translate them from English into Arabic and vice versa. The students' end product should be first evaluated by students themselves to find out their pragmatic errors; the evaluation of their teachers should be delayed.

\section{Bibliography}

1. Austin, John L. (1961). 'Performative Utterances', in Urmson, J. O. and Warnock, G. J. (eds.). Philosophical Papers. Clarendon: Oxford.

2. Baker, M. (1992). In Other Words: a Coursebook in Translation. Routledge: London.

3. Balim, A. and Wilks, Y. (1991). Artificial Believers: The Ascription of Belief. Hillsdale, NJ: Lawrence Erlbaum.

4. Bardovi- Harlig and Hartford, B. (1996). Input in an Institutional Setting. Studies of Second Language Acquisition, 18, 171-188

5. Bakiri, O. (in press). 'On the Relationship between Translation and Pragmatics', in Soyoye, Ayo (eds.). Reading in Modern Languages Studies in Nigeria.

6. Bell, R. (1991). Translation and Translating. Longman: London.

7. Blum-kulka, Shoshana. (1982). "Learning to Say what you Mean in a Second Language: A Study of the Speech Act Performance of Learners of Hebrew as a Second Language". Applied Linguistics 3(1): 29-59

8. Catford, J. (1965). A Linguistic Theory of Translation. OUP: New York.

9. Delisle, J. (1984). Bridging the Language Solitudes: Growth and Development of the Translation Bureau of the Government of Canada. Secretary of State.

10. Ehrman, J. F. (1993). Pragmatic and Translation: The Problem of Presupposition. Retrieved April $30^{\text {th }}, 2011$ from http://id.erudit.org/iderudit.

11. Ellis, . (1994). The Study of Second Language Acquisition. Oxford/ Oxford University Press. 
12. Hatim, B. and Munday, J. (2004). Translation: an Advanced Resource Book. Routledge: London.

13. House, J. (2001). 'Translation Quality Assessement: Linguistic Description versus Social Evaluation', in Meta: Translator's Journal, vol. 46. Retrieved on January, $19^{\text {th }} 2010$ from http://id.erudit.org/documentation/eruditPolitiqueUtilisation.pdf

14. Hymes, D. (1964). "Directions in (ethno) Linguistic Theory". American Anthropologist, 6(3/2): 6-56

15. Inga, R. (1991). "Translation Theory: Four Fundamental Aspects", in Dollerup, C. And Loddegaard, A. (eds.) Teaching Translation and Interpreting. John Benjamins Publishing.

16. Kasper, G. (1997). Can Pragmatic Competence be Taught? Retrieved 25 June, 2012 from www.lll.hawaii.edu/hflrc/NetWork/default.html

17. Kiraly, D. C. (1995). Pathway to Translation: Pedagogy and Process. Kent, Ohio: Kent State University Press.

18. Koller, W. (1977). 'aquivalenz in KontrastiverLinguistik und Usersetungswissenschaft', in Grahs, G. and Korlen, B. (eds). Theory and Practice of Translation. Nobel Symposiun39. L. Peter Lang: Bern.

19. Ladmiral, J. R. (1977). La Traduction. Swets and Zeitlinger. Amsterdam.

20. Lonsdale, A. B. (1993). Teaching Translation from Spanish to English: Worlds beyond Words. University of Ottawa Press.

21. Mauriello, G. (1991). "Teaching Tools in Translation Class", in Dollerup, C. and Loddegaard, A. (eds.) Teaching Translation and Interpreting. John Benjamins Publishing Company.

22. Newmark, P. (1981). Approaches to Translation. Prentice Hall: Hemel Hempstead.

23. Newmark, P. (1991). About Translation. Library of Congress: UK.

24. Nida, E. (1964). Towards a Science of Translation. E. J. Bill: Leiden.

25. Nida, E. and Taber, C. R. (1982). The Theory and Practice of Translation. E. J. Bill: The Netherlands.

26. Rose, K. R. (1994). Pragmatic Consciousness Raising in an EFL Context. Pragmatics and Language Learning Monograph Series, 5, 52-63

27. Thomas, J. (1983). "Cross-cultural Pragmatic Failure". Applied Linguistics. 4: 91-112.

28. Wilss, W. (1982). The Science of Translation: Problems and Methods. GenterNarrVerlag: Tubingen.

29. Yule, G. (1996). Pragmatics. Oxford: OUP. 